\title{
TEACHER-STUDENT RELATIONSHIP HARMONY AND STUDENT LEARNING OUTCOMES IMPRINTED BY TEACHER CLASSROOM MANAGEMENT STYLES AT A HIGHER EDUCATION INSTITUTION
}

Vu Van Tuan*, Nhac Thanh Huong, La Nguyen Binh Minh

Hanoi Law University

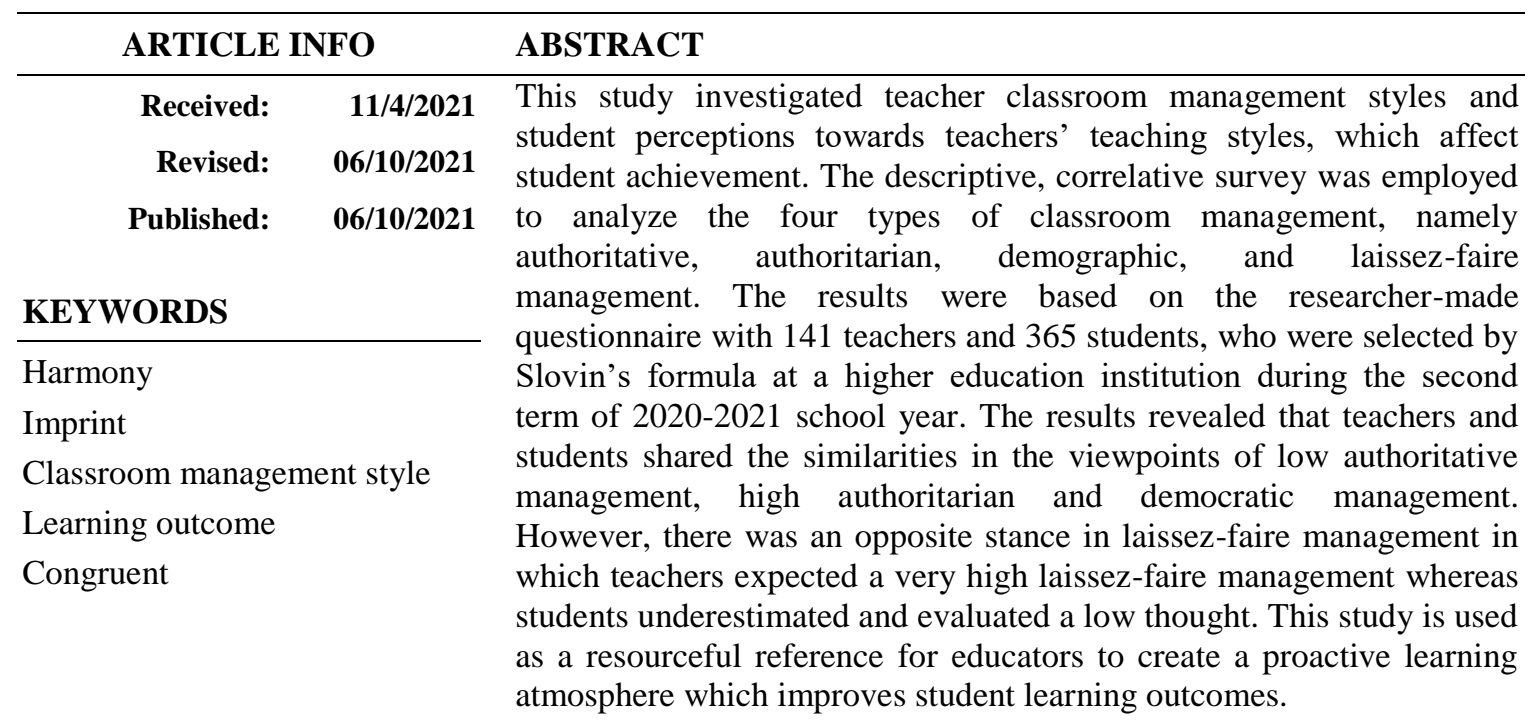

\section{SỬ HOÀ HỢP MỐI QUAN Hệ GIẢNG VIÊN - SINH VIÊN VÀ KẾT QUẢ HỌC TÂPP CỦA SINH VIÊN Ả̉NH HƯởNG BỞI CÁCH QUẢN LÝ LỚP HỌC CỦA GIẢNG VIÊN TẠI MỘT CƠ SỞ GIÁO DỤC ĐẠI HỌC}

Vũ Văn Tuấn", Nhạc Thanh Hương, Lã Nguyễn Bình Minh

Truờng Đại học Luật Hà Nội

\begin{tabular}{|c|c|}
\hline THÔNG TIN BÀI BÁO & TÓM TẮT \\
\hline Ngày nhận bài: $\quad$ 11/4/2021 & Nghiên cứu này xem xét cách quản lý lớp học của giảng viên và cảm \\
\hline Ngày hoàn thiện: $06 / 10 / 2021$ & nhận của sinh viên đối với phong cách giảng dạy của giảng viên ảnh \\
\hline Noày đăng: 06/10/2021 & $\begin{array}{l}\text { hương den thanh qua học tạp cua sinh vien. Khao sat so sanh, mieu ta } \\
\text { được sử dung để phân tích bốn phong cách quản lý lớp hoc của giảng }\end{array}$ \\
\hline 1. gay uatig. $00 / 10 / 2021$ & viên đó là cách quản lý quyền lực, độc đoán, dân chủ, và trao quyền. \\
\hline TÙ KHÓA & Kết quả của nghiên cứu dựa trên bảng câu hỏi do người nghiên cứu \\
\hline Sự hoà hợp & thức Slovin tại một cơ sở giáo dục đại học trong kỳ 2 năm học $2020-$ \\
\hline Ghi dấu & 2021. Kết quả đã chỉ ra rằng giảng viên và sinh viên có chung quan \\
\hline Phong cách quản lý lớp học & điêm đánh giá thâp vê cách quản lý lớp học quyên lực, đánh giá cao vê \\
\hline Kết quả học tập & $\begin{array}{l}\text { quản lý độc đoán, và dân chủ. Tuy vậy, họ có sự đôi lập quan điêm vê } \\
\text { cách quản lý trao quvền, đó là giảng viên rất thích trao quyền cho sinh }\end{array}$ \\
\hline Hài hoà & $\begin{array}{l}\text { viên, ngược lại sinh viên lại đánh giá thấp và không muốn được giảng } \\
\text { viên trao quyền. Nghiên cứu này là nguồn dữ liệu tham khảo hứu ích } \\
\text { cho nhà giáo dục để xây dựng môi trường học năng động nhằm nâng } \\
\text { cao kêt quả học tập cho sinh viên. }\end{array}$ \\
\hline
\end{tabular}

DOI: https://doi.org/10.34238/tnu-jst.4313

\footnotetext{
* Corresponding author. Email: vuvantuanphd@gmail.com
} 


\section{Introduction}

To evaluate the success of an academic program, student learning outcome is a satisfactory answer to the aforementioned issue. In fact, a successful teaching practice involves a series of necessary factors such as classroom climate, curricula, and educational policies. One of the essential determinants in determining the success of teaching and learning accounts for the role of teacher classroom management styles. Obviously, the interpersonal relationship between teachers and students plays an important part in deciding the successful achievement in the teaching and learning process. Throughout the history of teaching, many teaching approaches have been implemented; a decent shift of innovative teaching method is highlighted by the interchanged roles from teacher-centered teaching to learner-centered teaching [1], which promotes learner autonomy [2]. Simultaneously, the conversion from a yearly-based program to a credit-based system at the tertiary level in Vietnam has a far-reaching consequence on the interpersonal relationship in that the interaction and exchange among teacher-student, and student-student in a credit-based class are not firmly closed.

A friendly and casual classroom climate assures a positive and active atmosphere for the learning activities to take place, which makes teachers and students feel at ease to conduct the learning and teaching procedures productively and effectively. The efficient practices of classroom management and disciplines [3] enable educators to create the culture of being eager to be successful in terms of educational perspective. A proactive learning environment depends greatly on the implementation of teacher methodological teaching, especially the congruent classroom management. Some researchers [4] - [6] emphasize the crucial role of teacher classroom management styles, particularly the interpersonal relationships between the teachers and students inside and outside schooling environment. Richards and Schmidt [7] define classroom management in language teaching as the ways in which student behaviour, movement or interaction during a class are organized and controlled by the teacher (or sometimes by the learners themselves) to enable teaching to take place most effectively. Classroom management includes procedures for grouping students for different types of classroom activities, use of lesson plans, handling of equipment, aids, and the direction and management of student behaviour and activity. Norris [8] claims that classroom management is likened to parameters for social, emotional, physical environment where teachers feel more in control and competent in case they have a good, efficient plan for discipline and teaching procedures. This allows for optimized teaching and learning to occur.

Classroom environment is significantly influenced by teacher decision on classroom management styles (CMS) which have a great impact on the interpersonal relationship or interactions with students. This rapport might denote either positive or negative interactions between teachers and students. As a result, CMS correlate closely with different moods in student behaviour. Evaluating CSM is not new but not very common at the tertiary level. In the previous studies [9], [10], researchers have investigated the influence of CMS in different aspects. Lewin's leadership style [9] puts forward three basic approaches to CMS such as authoritarian, democratic, and laissez-faire styles. This study, however, focuses only on the characteristics of CMS in general, not specific to any educational level. Giang and Nga [10] carried out a research on the congruency of classroom management styles and teacher-student relationship towards student learning outcomes. They examined this relationship in 5 styles, namely authoritarian, autocratic, democratic, laissez-faire, and eclectic styles. They came to a conclusion that the great influence was disclosed under the impact of teacher teaching styles. In this study, the contrastive comparison between teachers and students has not been clearly reflected. Overviewing CMS, this issue has not paid much attention as most teachers use different classroom management styles which affect how students connect, avail, and communicate with their teachers. The CMS influence students in terms of how they view school as a learning place and how they view their 
teachers who are considered as the frontiers of knowledge building, and have a significant impact in their learning process. This study was conducted to answer the following questions;

1. What is the classroom management style of the teachers as assessed by the students and the teachers themselves?

2. What typifications or labelling do the students attach to authoritarian, authoritative, democratic and laissez faire teachers in their school?

\section{Materials and methods}

\subsection{Research design}

This study was primarily conducted to examine the relationship between teacher and student interactions at a higher institution education, influencing student learning outcomes. A case study was implemented at Hanoi Law University, involving 141 teachers, and 365 students, using Slovin's formula to select the participants from the list of random. Two sets of researcher-made questionnaire were floated to seek for the respondents' beliefs about CMS. The letter from the researcher attached to the questionnaire explained the aims and relevance of the study, assuring the respondents of anonymity and giving them the option of not participating in the study if they wished. The raw data was screened and treated with IBM SPSS application for the purpose of data analysis.

\subsection{Sample population}

This case study was conducted at Hanoi Law University, using Slovin's formula to select the sample population. 141 out of 220 teachers participated in this survey, particularly 57 male teachers accounting for $40.4 \%$, and 84 female lecturers $(59.6 \%)$. Their highest academic status included 82 masters $(58.2 \%), 35$ doctors $(24.8 \%), 24$ associate professors (17.0\%), and neither professors nor bachelors. For the length of service, teachers who had less than 5 years were 11 teachers $(7.8 \%), 59$ lecturers $(41.8 \%)$ served less than 10 years in teaching, 38 participants $(27.0 \%)$ underwent less than 15 teaching years, 18 lecturers $(12.8 \%)$ experienced less than 20 years on teaching jobs, and 15 teachers $(10.6 \%)$ lectured over 20 years. As regard to faculty participation, there were Faculty of Political Theories with 14 teachers (9.9\%), Faculty of Administrative and Constitutional Law with 24 lecturers (17.0\%), 21 instructors (14.9\%) in Faculty of Criminal Law, 23 teachers (16.3\%) in Faculty of Civil Law, 25 lecturers (17.7\%) in Faculty of Economic Law, Faculty of International Law with 16 instructors (11.3\%), 11 teachers (7.8\%) in Faculty of International Trade Law, and 7 lecturers (5.0\%) in Department of Foreign Languages.

In addition, Slovin's formula was also employed to shortlist the student participants; 365 out of 7000 students were officially chosen in which 247 female students $(67.7 \%)$, and 118 male ones $(32.3 \%)$ took part in this survey. The participants belonged to 4 courses, namely course 42 including 30 students $(8.2 \%)$; course 43 with 65 ones $(17.8 \%) ; 139$ students $(38.1 \%)$ in course 44; and course 45 having 131 students (35.9\%). They also came from 4 majors, particularly 176 students (48.2\%) major in law; 86 students (23.6\%) learning economic law; 71 students $(19.5 \%)$ major in international trade law; and 32 ones (8.8\%) learning legal English.

\subsection{Research instrument}

The study employed the researcher-made questionnaires for teachers and students separately. The questionnaires were constructed to investigate 4 aspects, particularly authoritarian, authoritative, democratic, and laissez-faire management styles. The questionnaires were consulted by 3 experts on educational management and psychology for content validation; then, these research instruments were implemented with 5 volunteer teachers and 45 students in pilot studies before being fine-tuned for the final versions. To assure the liability of the questionnaires, the items which ranged reliably within the Alpha values $(\alpha=0.84-0.90)$ [11] were selected. 
Finally, 24-questionnaire items for teacher as well as student assessment were presented to 3 educational experts again for the assurance of the liability.

\subsection{Data analysis}

The quantitative data were analyzed using descriptive statistics. Specifically, frequency count, percentage and mean were used to analyze the profile of the teacher and student respondents. The Likert scales were used to determine the extent that participants' rates were classified into, namely very low (1.0 - 1.8), low (1.9 - 2.6), neutral (2.7 - 3.4), high (3.5 - 4.2), and very high (4.3 - 5.0). In addition, Pearson Product Moment Correlation was used to correlate the typifications students labelled to the teachers.

\section{Results and discussion}

\subsection{Authoritative management}

When comparing between the assessment of teacher and student participants in terms of authoritative management, the disparity between two groups is revealed. Teacher participants had low perspectives for the authoritative management. In particular, they believed that if a student was disruptive during class, they removed him/her from the classroom, without further discussion $(M=2.15 ; S D=0.632 \%)$. They disagreed to reckon that the classroom had to be quiet in order for students to learn $(M=1.99 ; S D=0.621 \%)$. They also refuted to think that they did not accept excuses from a student who was tardy $(M=198 ; S D=0.554 \%)$. In contrast, student respondents had neutral viewpoints on the authoritative management. They thought that they learnt much even if their teacher punished them without further discussion $(M=2.03 ; S D=0.544 \%)$. They additionally claimed that they learnt much when their teacher ensured that the classroom had to be quiet in order for them to learn $(M=2.37 ; S D=0.596 \%)$, and they also remarked that they learnt much when their teacher did not accept excuses when they were tardy $(M=2.02 ; S D=$ $0.562 \%)$. On average, the respondents had similar choices in that the standard deviation figures were under $1.0 \%$, which reflected that they had their choice in common. Authoritative management can be named as "coaching," or "selling" style. It is characterized by behavioral principles, high expectations of appropriate behavior, clear statements about why certain behaviors are acceptable and others not acceptable, and warm student-teacher relationships. For this kind of CMS, the high level of student involvement that comes with authoritative management often fosters a high level of student self-motivation [8], [10]. Encouraging discussions helps to build social competence. The mixture of lecturing and class discussions makes it easy for the teacher to put variety into the class period, which increases attentiveness. It is, nonetheless, least effective when teammates are defiant and unwilling to change or learn, or if the leader lacks proficiency [3]. In this regard, teachers seemed to constrain the impulse involvement of students into the learning process. They wanted to control and supervise all student activities.

\subsection{Authoritarian management}

In regard to the authoritarian management, teachers had positively very high perspectives for this kind of classroom management. They firmly asserted that they always tried to explain the reasons behind their rules and decisions $(M=4.5 ; S D=0.723 \%)$. They expressed their opinions on their concerns about both what their students learnt and how they learnt $(M=4.39 ; S D=$ $0.725 \%$ ), and they claimed to understand and sympathize with their students to interrupt their lecture if students have a relevant question $(M=4.38 ; S D=0.528 \%)$. Meanwhile, their students also had high attitudes towards the authoritarian styles. The results showed that students learnt much when their teacher was concerned about both what they learnt and how they learnt $(M=$ 4.04; $S D=0.591 \%)$. They thought they learnt much when their teacher always tried to explain 
the reasons behind his/her rules and decisions $(M=4.05 ; S D=0.562 \%)$. Furthermore, they confirmed to learn a lot when their teacher allowed them to be interrupted during his/her lecture if they had a relevant question $(M=4.03 ; S D=0.568 \%)$. Seeing the characteristics, the authoritarian, "coercive", or autocratic style is characterized by numerous behavioral regulations, and is often seen as punitive and restrictive, and students have neither a say in their management, nor are they seen to need explanations [9]. Thus, the teacher's character is sometimes perceived as being cold, even punishing. They have full control of the team, leaving low autonomy within the group [8]. Therefore, the findings proved that teachers acknowledged to have a very high extent of bossy, cold manners, which also supported by the high degree of student confirmations.

\subsection{Democratic management}

Concerning the democratic management, teachers highly thought that they did not want to impose any rules on their students $(M=4.01 ; S D=0.621 \%)$. They argued strongly with high remarks that if a student turned in a late homework assignment, it was not their problem $(M=$ 4.17; $S D=0.609 \%)$. They reckoned that if a student requested to leave the room, they always honored the request $(M=4.24 ; S D=0.675 \%)$. As far as student participants were concerned, they claimed high comments on the democratic management. The results indicated that they learnt much even if their teacher did not want to reprimand them because it might hurt their feelings $(M=4.00 ; S D=0.567 \%)$. They highly believed that they learnt much when their emotional well-being was given more importance by their teacher than classroom control $(M=$ 3.98; $S D=0.562 \%$ ), and they also confirmed that they learnt much when their teacher always honoured their request for an excuse $(M=4.05 ; S D=0.565 \%)$. For democratic management, it refers to the democratic teacher who places few demand or controls on the students. Teachers' typical characteristics show indifferent or "permissive" teachers who are not very involved in the classroom, who have a tendency to allow their students to do their own things. As reflected from the aforementioned findings, teachers accept the student's impulses and actions and are less likely to monitor their behavior [6], [10]. In fact, teachers try to not hurt student's feelings and have difficulties saying 'no' to a student or enforcing rules. If a student disrupts the class, he/she may assume that he/she is not giving that student enough attention [9]. The findings reveal that teachers are more concerned with students' emotional well-being than they are with classroom control. The result indicates that teachers bases classroom decisions on their students' feelings rather than on their academic concerns. Learning with this sort of CMS, students enjoy a lot of freedom as the classroom discipline is lacking. Accordingly, very little learning occurs, so students have low achievement motivation and lack self-control.

\subsection{Laissez-faire management}

Teacher participants had a quite high opinion on the laissez-faire management. In particular, they claimed that they did not want to reprimand a student because it might hurt his/her feelings $(M=4.2 ; S D=0.606 \%)$. They supposed that the emotional well-being of their students was more important than classroom control $(M=4.21 ; S D=0.683 \%)$. Furthermore, they believed that class preparation was not worth the effort $(M=4.27 ; S D=0.425 \%)$. Student participants, however, had different ideas when recording a low evaluation. Specifically, they stated that they learnt much even if their teacher did not want to impose any rules on them $(M=2.50 ; S D=0.698 \%)$. In addition, they confessed that they learnt much even if their teacher did not bother when they turned in a late homework/assignment $(M=2.07 ; S D=0.540 \%)$, and they also learnt much even if their teacher's class preparation was not worth the effort $(M=2.48 ; S D=0.721 \%)$. For the laissez-faire management, it is an "indulgent" or "delegative" so-called style. Teachers have typical characteristics of preferring their students to like them and they want to be helpful, so they are warm and supportive but not very good at setting limits. They concentrate on effort while de-emphasizing the quality of students' productions. Their characters also reflect when 
disruptive behavior may be ignored or handled with weak, soft-spoken "reprimands" or pleading. As glimpsed from the findings of students, they do not want their teachers to apply this kind of CMS. With few demands placed upon them, these students frequently have lower motivation to achieve, which results from the fact that students lack the knowledge or experience they need to complete tasks and make decisions. Otherwise, students do not like the laissez-faire style because this overindulgent style is associated with students who do not have much social competence and self-control [8], [10]. Thus, it is difficult for them to learn socially acceptable behavior when the teacher is so permissive. It is better for this kind of teachers to apply in the situations where students have a high-level of passion and intrinsic motivation for their work, and they are actively supported in their effort to seek their own needs using reasonable means.

Table 1. Correlative comparison of the weighted mean among teachers and students in terms of CMS

\begin{tabular}{lcc}
\hline Classroom Management & Teacher & Student \\
\hline Authoritative management & 2.04 & 2.14 \\
Authoritarian management & 4.39 & 4.04 \\
Democratic management & 4.14 & 4.01 \\
Laissez Faire management & 4.23 & 2.35 \\
\hline
\end{tabular}

Table 1 presents the difference between the evaluation of teachers and students in terms of the overall mean scores for different kinds of CMS. The findings indicate that teachers do not prefer authoritative style, which supports the dominant role of teachers in the classroom, who have the authority to supervise all student activities, and take charge of student learning outcome. Similarly, student participants dislike being controlled tightly by their teachers. They wish to be instructed or guided what they should do, and consider their teachers as the advisors or mentors. As clearly seen from Table 1, there is no disparity among the participants regarding the authoritarian and democratic managements. For these CMS, the participants share the similarities in their stances. Laissez faire management is, however, different in that while teachers want to impose the laissez faire management for the sake of the easy environment for students to do their best, student participants see it as the lack of teachers' responsibilities and professional incompetence.

\section{Conclusion}

Examining teacher classroom management styles brings back the benefits for not only teachers but also students. As this field is not popularly paid attention and often neglected. This study, therefore, highlight some key points which help the educators and policy makers consult for the sake of providing better educational environments for active learning. Teacher respondents in this study show low attitudes towards the authoritative management. That is, they have negative and unsupportive relationships with their students and keep a little distance away from their students. As a result, their students lack creativity and have a tendency to be passive in learning, and have a poor academic performance. Both teachers and students remark highly on the authoritarian management. In particular, teachers are self-proclaimed to be bossy and cold while their students consider them as if their instructors were dictators in the classroom. This negative relationship does not promote students' autonomous learning or learner autonomy, and has a bad influence on the learning outcomes. In addition, teachers and students also share the similarities in showing high agreement on the democratic management, which denotes that teachers may lack skills, confidence or courage to discipline their students; therefore, it can lead to low student achievement motivation and self-control. There is an opposite opinion on Laissezfaire management. While teachers place few demands or control on their students, accepting students' impulses and actions, students dislike their teachers' CMS in this aspect. Thus, this management produces lower motivation for students to achieve, and their learning outcomes are highly dependent on their teachers' mood. 


\section{REFERENCES}

[1] J. Schreurs and R. Dumbraveanu, "A Shift from Teacher Centered to Learner Centered Approach," International Journal of Engineering Pedagogy (iJEP), vol. 4, no. 3, pp. 36-41, 2014. [Online]. Available: http://dx.doi.org/10.3991/ijep.v4i3.3395. [Accessed Apr. 8, 2021].

[2] P. Benson, "Learner Autonomy," TESOL Quarterly, vol. 47, no. 4, pp. 839-843, 2013. [Online]. Available: https://doi.org/10.1002/tesq.134. [Accessed Apr. 8, 2021].

[3] J. P. Barile, D. K. Donohue, E. R. Anthony, A. M. Baker, S. R. Weaver, and C. C. Henrich, "TeacherStudent Relationship Climate and School Outcomes: Implications for Educational Policy Initiatives," Journal of Youth and Adolescence, vol. 41, pp. 256-267, 2012. [Online]. Available: https://doi.org/10.1007/s10964-011-9652-8. [Accessed Apr. 5, 2021].

[4] L. Jung-Sook, "The effects of the teacher-student relationship and academic press on student engagement and academic performance," International Journal of Educational Research, vol. 53, pp. 330-340, 2012. [Online]. Available: https://doi.org/10.1016/j.ijer.2012.04.006. [Accessed Mar. 25, 2021].

[5] H. Gehlbach, M. E. Brinkworth, and A. D. Harris, "Changes in teacher-student relationships," British Journal of Educational Psychology, vol. 82, pp. 690-704, 2012. [Online]. Available: https://doi.org/10.1111/j.2044-8279.2011.02058.x. [Accessed Mar. 25, 2021].

[6] G. Hagenauer and E. V. Simone, "Teacher-student relationship at university: an important yet underresearched field," Oxford Review of Education, vol. 40, no. 3, pp. 370-388, 2014. [Online]. Available: https://doi.org/ 10.1080/03054985.2014.921613. [Accessed Mar. 25, 2021].

[7] J. C. Richards and R. W. Schmidt, Longman Dictionary of Language Teaching and Applied Linguistics, 4th ed. Routledge, 2014, p. 81, doi:10.4324/9781315833835.

[8] J. A. Norris, "Looking at Classroom Management through a Social and Emotional Learning Lens," Theory into Practice, vol. 42, no. 4, pp. 313-318, 2003. [Online]. Available: www.jstor.org/stable/1477394. [Accessed 23 Mar. 2021].

[9] K. Lewin, "Patterns of aggressive behavior in experimentally created social climates," Journal of Social Psychology, vol. 10, no. 2, pp. 271-299, May 1939. [Online]. Available: https://tudresden.de/mn/psychologie/ipep/lehrlern/ressourcen/dateien/lehre/lehramt/lehrveranstaltungen/Lehrer_ Schueler_Interaktion_SS_2011/Lewin_1939_original.pdf?lang=en. [Accessed Mar. 23, 2021].

[10] B. T. K. Giang and T. T. T. Nga, "Classroom Management Styles and Teacher-Student Relationship Congruency: Its Influence on Student Learning Outcomes," TNU Journal of Science and Technology, vol. 199, no. 6, pp. 11-16, 2019. [Online]. Available: https://doi.org/10.34238/tnu-jst.2019.06.333. [Accessed Mar. 20, 2021].

[11] L. J. Cronbach, "Coefficient alpha and the internal structure of tests," Psychometrika, vol. 16, no. 1, pp. 297-334, 1951. [Online]. Available: https://doi.org/10.1007/BF02310555. [Accessed Mar. 8, 2021]. 